https://helda.helsinki.fi

\title{
The Asymmetric approach in Russian Security Strategy : Implications for the Nordic Countries
}

\section{Pynnöniemi, Katri Pauliina}

2019-01-02

Pynnöniemi , K P 2019 , ' The Asymmetric approach in Russian Security Strategy :

Implications for the Nordic Countries ' , Terrorism and Political Violence , vol. 31 , no. 1 , pp.

154-167 . https://doi.org/10.1080/09546553.2018.1555995

http://hdl.handle.net/10138/318564

https://doi.org/10.1080/09546553.2018.1555995

acceptedVersion

Downloaded from Helda, University of Helsinki institutional repository.

This is an electronic reprint of the original article.

This reprint may differ from the original in pagination and typographic detail.

Please cite the original version. 


\title{
The Asymmetric Approach in Russian Security Strategy: Implications for the Nordic Countries
}

\author{
Katri Pynnöniemi
}

\section{QUERY SHEET}

This page lists questions we have about your paper. The numbers displayed at left can be found in the text of the paper for reference. In addition, please review your paper as a whole for correctness.

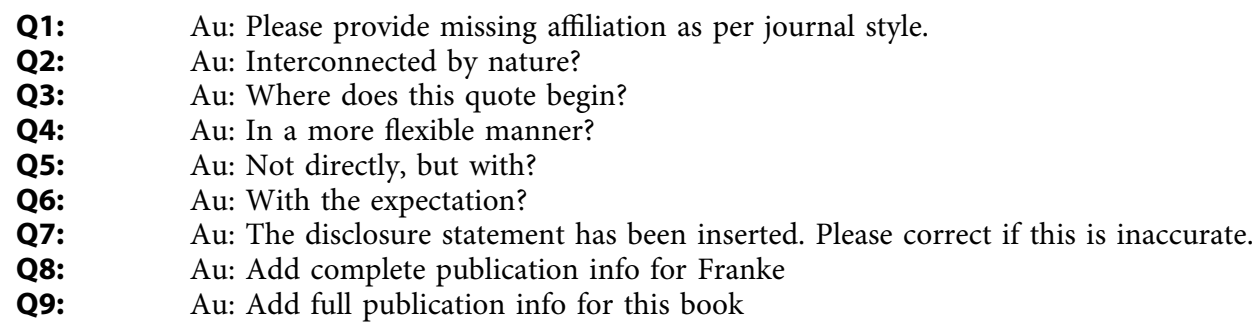

\section{TABLE OF CONTENTS LISTING}

The table of contents for the journal will list your paper exactly as it appears below:

The Asymmetric Approach in Russian Security Strategy: Implications for the Nordic Countries Katri Pynnöniemi 


\title{
The Asymmetric Approach in Russian Security Strategy: Implications for the Nordic Countries
}

\author{
Katri Pynnöniemi
}

\begin{abstract}
Two observations stand out from the Russian strategic outlook. First, it corresponds with the real politik vision of world politics where the states engage in (zero-sum) competition for power and resources. Second, the new world order emerges because of a conflict between different models of development and value systems. These two observations highlight a certain "family resemblance" between the current Russian assessment of the current security environment and the situation during the Cold War. Furthermore, Russian national security strategy is oriented toward achieving strategic stability with the other great powers. The maintenance of strategic parity (nuclear and conventional deterrence) is a means to this end. However, given Russia's relative weakness in comparison to its major geopolitical competitors, this has led to the renewal of the Cold War-era concept of asymmetric approach. Although this concept is most often used in the context of nuclear deterrence and the debate on "strategic stability," it is not about military security only. The set of asymmetric measures from economic dependence or sanctions, to diplomatic, political, and informational measures are used to prevent an emergence of a conflict that would threaten Russia's sovereignty and domestic stability. The purpose of this paper is to explore the Soviet roots of Active Measures and how the Soviet heritage is present at both the theoretical level and in concrete practices. Finally, insights from the conceptual analysis are applied in assessing the vulnerability of the Nordic countries, in particular Finland and Sweden, to Russian influence operations.
\end{abstract}

\section{KEYWORDS}

Russian information influence; Cold War; Active Measures; Soviet propaganda; reflexive control; Sweden; Finland

\section{Introduction}

The current Russian national security strategy was adopted in December 2015. ${ }^{1}$ The new version replaced the strategy prepared during the Medvedev presidency in 2010. The strategy juxtaposes positive achievements, such as Russia's "independent foreign and domestic policy," against the background of negative developments and intensifying threats towards Russia. Accordingly, "the strengthening of Russia is taking place against a backdrop of new threats to national security that are multifarious and interconnected nature." 2 The strategy portrays Russia as an actor that is not fully able to realize its national interests. The reason for this is the "West's stance" on the Eurasian integration process that is "exerting negative influence on the realization of Russia's national interests." 3 Although the text does not make direct reference to Ukraine, from the context it can be assumed that the question is about Ukraine's reluctance to embrace a Russia-led Eurasian economic integration project. $^{4}$ 
Overall, the strategy frames the ongoing regional and local conflicts as a part of larger change, whereby "a new polycentric model of the world order" is taking shape. This process is "accompanied by an increase in global and regional instability" and growing competition between social development values and models, as well as, competition for scientific, human and technological potential." ${ }^{5}$ In fact, Russian strategic documents identify the competition for natural resources as a major driver of instability in international politics. ${ }^{6}$ This type of argumentation exemplifies the real politik vision of world politics where the states engage in (zero-sum) competition for power and resources. The final outcome of this struggle, as suggested in the above, is an emergence of new "world order," that is, a new state of equilibrium between the major powers. ${ }^{7}$ Thus, the new world order equals "strategic stability" that is defined in the National Security Strategy as a state of affairs (between the great powers) "based on the principles of equality, mutual respect, noninterference in states' internal affairs, mutually beneficial cooperation, and a political settlement of global and regional crisis situations." 8

The strategic documents identify the preferred future trajectory of world politics. The initial reactions from the Russian research community to the conflict in Ukraine interpreted it as "a final nail in the coffin of the cold war" and an opportunity to re-negotiate the European security architecture. The worsening of the conflict in summer 2014 (after the downing of a MH17 on July 17, 2014), according to Sergei Karaganov, a well-known foreign policy analyst, suggested that although Russia's ability to craft the "Russian World" out of thin air was no longer in doubt, the use of Active Measures in the neighbouring country was not without risks. Here Karaganov refers to the economic sanctions but also to the possibility that the large quantities of armaments and groups of armed men fighting in the Eastern Ukraine would have a negative impact in the neighbouring regions of Russia. ${ }^{10}$ A similar conclusion drawn to the above-mentioned is found in the strategic documents that emphasize a heightened sense of military and non-military threats towards Russia. ${ }^{11}$

With hindsight, an expectation that Russia would become a stabilizer and "one of the key guarantors of global and regional stability" ${ }^{12}$ seems overly optimistic. In fact, the IMEMO forecast for 2015 observed, that "in 2014 in Russian political discourse there was no mentioning of the country's role as a 'counter-balance' and 'stabilizer' of world international relations." ${ }^{\prime 3}$ The 2017 analysis takes an even more conservative view on the larger change, arguing that the "current post-order condition of world politics is unlikely to herald a transition to a new world order in the years to come." The point is that none of the major players of world politics can push forward its vision of the new order. Instead, all the players are preparing for the "big bargain"-trying to shape the conditions of a new era to gain maximum economic and political benefit. ${ }^{14}$

The latest IMEMO forecast (2018) takes note of Russia's increased activity in managing regional crises (an explicit reference to Syria), heightened "anti-Russian" fervor in the Western media, and concludes that the continuing crisis in Ukraine is the major impediment of cooperation. However, it concludes that a compromise achieved in the settlement of the crisis in Ukraine would be a major boost for Russian foreign policy and economic development. ${ }^{15}$ A much more common approach to this situation, expressed in the abovementioned security documents, is to emphasize Russia's resolve in defending its national security interests and the importance of an asymmetric approach in achieving this goal. ${ }^{16}$ With this concept it is argued that Russia is engaged in the active defence of its national security interests, including the use of Active Measures in preventing or neutralizing the 
emergence of a conflict that would threaten Russia's sovereignty and domestic political stability. The next section will discuss in more detail how this idea has evolved in the Russian debate on security and military policy.

\section{The asymmetric approach: active defence of national interests}

The concept of "asymmetric approach" has a rich history both in Western and Russian military thought. ${ }^{17}$ In the Russian context, the term "strategic asymmetry" was used in the late 1980 s as a response to the US Strategic Defence Initiative and implied a task to use vulnerabilities in a system to the Soviet Union's advantage. In the post-Cold War environment, the retired army general and President of the Russian Academy of Military Science, Makhmut Gareev, saw indirect actions as a means to prevent wars and military conflicts. According to Gareev, the relative weight of indirect actions would increase in the future. This was mainly because of three factors: nuclear deterrence, a tendency for the maximum preservation of professional armies, and the refusal of direct support of conflicts by the great states. ${ }^{18}$

Later, however, Gareev pinpointed practical reasoning for asymmetric actions as stemming from the fact that "Russia's economic and military might is incommensurable with the capabilities of the former Soviet Union and the United States." Given this situation, Gareev argued, "we must respond to emerging threats in a more flexible and, if possible, not direct, but asymmetric measures." He went on to define asymmetric approach as a set of interrelated political, diplomatic, information, economic, military, and other measures that deter, reduce, or avert threats of unacceptable consequences as a result of retaliatory actions. Although Gareev emphasizes the role of asymmetric actions as means of preventing a conflict, another interpretation is implicit as well. ${ }^{19}$ Using a full spectrum of means from political, informational, economic, financial, and military spheres, the adversary can be put into a defensive posture and off balance, and thus, conditions are created for (potential military) surprise. ${ }^{20}$ This idea was written into the 2009 National Security Strategy and appears also in the new version of the strategy. Accordingly, asymmetric measures, such as economic, informational, cyber, and diplomatic resources are used "to prevent the use of armed force against Russia, and to protect its sovereignty and territorial integrity." 21

The renewed Russian Military Doctrine goes further. Accordingly, the basic features of modern conflicts include the synchronized use of the military force together with political, economic, information, and other non-military measures and the protest potential in the society. ${ }^{22}$ In Russian thinking, these measures are seen as part of the geopolitical struggle between the great powers. ${ }^{23}$ Furthermore, it is assumed that foreign countries try to undermine Russia's political stability by "remote controlling" groups that are critical towards the political leadership of the country. ${ }^{24}$ What is not problematized in this debate are the ways in which Russian authorities themselves use "political technologies" 25 to manipulate domestic public perceptions. The following sections review the evolution of three different but complementary concepts: organizational weapon, reflexive control, and Active Measures. Taken together these concepts describe what the asymmetric approach is about.

\section{The Soviet roots of asymmetric approach}

It is perhaps ironic, but not at all surprising, that on the eve of the 100-year anniversary of the October Revolution, the Russian Security Council has commissioned a study on how to 
prevent the emergence of a "romantic revolutionary" stereotype and the formation of an "aggressive managed (upravlyaemoi) mob" in Russia. The research project is studying how Russia could take better advantage of so-called "soft power" to protect its national interests. ${ }^{26}$ This project should be viewed as a continuation of a trend rather than a new phenomenon. Already in 2000 the information security doctrine set clear parameters on how the Russian state aspired to achieve "information superiority" in the domestic sphere. The National Security Strategy from 2009 identified "nationalist, separatist, radical religion and other agitation" as a danger to the Russian state. The new version of the strategy, accepted in late 2015 , is more specific on these threats, and outlines what can be considered programmatic content for the protection of Russian spiritual and historical values. ${ }^{27}$

The underlying idea expressed in one form or another in this debate is derived from Lenin, who asserted that propaganda should be a matter of action rather than words. ${ }^{28}$ In the Soviet propaganda campaigns that followed, this idea was interpreted to mean that all agitation should be tied to some concrete goal. ${ }^{29}$ However, the basic idea goes further than that. Writing in 1906 in On Guerrilla Warfare, Lenin emphasized:

Marxism ... positively does not reject any form of struggle. Under no circumstances does Marxism confine itself to the forms of struggle possible and in existence at the given moment only, recognizing as it does that new forms of struggle, unknown to participants of the given period, inevitably arise as the given social situation changes. In this respect Marxism learns, if we may so express it, from mass practice, and makes no claim whatever to teach the masses forms of struggle invented by 'systemizers' in the seclusion of their studies. ${ }^{30}$

This idea of working with material-interpreted in the widest possible sense from a situational context to human and material resources available at a given moment-comes across in Soviet thinking (e.g., Trotsky) and subsequent Russian analyses. It does not signify a call for just any spontaneous action. On the contrary, Lenin was adamant that "secret, casual, unorganized guerrilla actions" were a recipe for the disorganization of the party, and consequently, the party's task was to "take such actions under its control." 31 At this point in time, Lenin's organizational weapon was aimed at two concrete goals: the assassination of political enemies and confiscation of monetary funds from both the government and private persons. ${ }^{32}$ However, in his previous writing on the lessons of the Moscow Uprising (1905), Lenin argued that party activists should learn from this experience and help the masses by stimulating their creative efforts, and thus further the development of what Lenin called "new barricade tactics." 33 Therefore, although Lenin relied on what has later become a trademark of the Russian approach to conflict, i.e., improvisation, he made it clear that the creativity of the masses should be controlled from above, that is, by the party functionaries.

Towards this end, a formal Department of Agitation and Propaganda was established under the Central Committee of the Communist party in August 1920. This department became known by its acronym agitprop, and its primary function was to coordinate the propaganda work of different Soviet institutions. ${ }^{34}$ Curiously, A Dictionary of Scientific Communism published in 1984 does not include the term propaganda, but does define what the stimulation of the creativity of the masses in the Soviet view meant. The idea was expressed with the concept of "political manoeuvring" defined as "the ability [of the party leadership] to direct the mass movement in the right way, depending on the objective situation." Depending on the "ebb" and "flow" of the revolutionary moment, the manoeuvring could take the form of a political offensive, retreat, defence, and mustering of forces. ${ }^{35}$ 
In the context of more theoretically oriented debates on warfare and information war in particular, political manoeuvring is known by another name. An organizational weapon is the creative energy of the masses organized and directed by the authorities to hit a specific target. ${ }^{36}$ Writing on Soviet psychological warfare, Wilbur Schramm provides the following explanation for this concept:

The word does not typically stand alone in Soviet planning. From the very first, Communists were told by their leaders that words were not enough, that words had to merge with deeds, and both into organization... . When we try to describe Soviet psychological operations, therefore, we talk not so much about a word weapon as about an organization weapon. ${ }^{37}$

This concept is not used in current Russian military literature; for example, there is no such entry in the Encyclopedia of Information-Psychological War from 2011. ${ }^{38}$ In the framework of public and populist oriented debate, several different meanings are attached to this concept. For example, it has been referred to as a rough equivalent of "network-centric warfare." 39 Other examples include the characterization of ISIS as an organizational weapon and the claim made by economist Sergei Glazyev that "strategic planning" can be regarded as a powerful organizational weapon. ${ }^{40}$ In fact, Izborskii Klub, a well-known community of conservative-patriotic thinkers, including the above-mentioned Glazyev, seems to have developed this concept further, or at least uses it systematically in its writings. In an essay titled "Organizational Weapons: The Functional Emergence and System of a 21st-century Technology" published in late 2013, the origins of the concept are traced to Aleksandr Bogdanov, a developer of universal organization theory, an early version of cybernetics. ${ }^{41}$ The community's interest towards Bogdanov has most likely been guided by his work on the "scientific systematization of humanity's organizational experience in its entirety," 42 which he called tectology but in which the authors of the above-mentioned essay saw the roots of the concept of organizational weapon.

However, the concept of "organizational weapon" is rarely used beyond expert discussion. Instead, an idea of externally organized revolt or mass-protests aimed to overthrow the legitimate government is expressed with the concept of colour revolution. ${ }^{43}$ This term refers to political conflicts that developed in several post-Soviet countries (Georgia 2003, Ukraine 2004, Kirgisia 2005) during the 2000s. In the 2010s, especially after 2014, historical-regional connotation of this concept has given way to more analytical usage of the term "colour revolution." Gapich and Lushnikov argue that social changes, continuing global economic crisis, and actualization of the military-political aspect in international relations has led to the symbiosis of social-political non-violent methods of civic unrest with military strategy and tactics. To back up this claim, authors refer to several concepts, for example, "irregular warfare" and "small war," that describe the logic of colour revolutions. ${ }^{44}$ They refer to "specialists of political upheavals" but refrain from directly accusing the Western countries (namely the United States) of attempts to use these techniques against Russia.

After 2014, many popular books, and even some academic publications, have built their argument around this potential threat from the West. For example, an article published in the Russian military academy journal in 2017, named the United States as an agent, "creating of cataclysms designed to harm the security of single states and whole regions." 45 Authors present an analysis of "political regime transformation technology," pinpointing the reasons, mechanisms, and consequences of "nationhood destruction." 46 Their analysis is oriented at understanding the contemporary situation in Russia, with special focus on the presidential 
elections (March 2018), and possible attempts towards de-legitimation of the election result (and thus, the legitimation of the political system under Putin). Although this type of practice oriented analyses dominate the public debate, the majority of articles published by professional military analysts seek to explain interplay between transformation of warfare, the role of information war (understood broadly) in it, and specific Russian ways of war. A good example is A. Derbin's article where he integrates the civilizational dimension (world divided into Western and Eastern civilizations) with detailed analysis of what constitutes peace and war. Derbin divides the struggle for geopolitical power into political, economic, and information spheres, and makes a distinction between direct and indirect forms of aggression. The indirect forms include psychological, information, and other operations. Furthermore, the category of "other operations" includes hybrid, soft power, small intensity operations, sanctions, isolation and blockades, peacekeeping and humanitarian operations. ${ }^{47}$

Derbin's matrix builds on the assumption that the direct and indirect measures are a form of geopolitical struggle for power, as mentioned above, and thus, guided by state security interests. This is the frame of interpretation explaining political crises in the postSoviet space. Although historical-political connotations (a colour revolution understood as predominantly a post-Soviet phenomenon) have not been revoked, the focus of the debate has changed. The use of organizational weapon is analyzed in the framework of warfare where the organization of revolutionary situation is only a first stage towards a bigger goal: the struggle for (geo)political power.

\section{Shaping policies, sentiments, and perceptions with Active Measures}

In traditional understanding, an armed conflict (war) means the physical destruction of the enemy. At the same time, an attack can be regarded as successful when it leads to the "self-disorganization" and "self-disorientation" of the adversary, and the subsequent capture of the enemy's resource base and its usage to the benefit of the attacker. ${ }^{48}$ The theory of reflexive control, intensively developed by Soviet military and civilian theorists since the early 1960s, explains and provides practical means for achieving the "selfdisorganization" of the enemy. According to V. A. Lefebvre, one of the thinkers behind the theory, reflexive control is "a process by which one enemy transmits the reasons or bases for making decisions to another." 49 As explained by Tim Thomas, an expert on 250 Russian information war:

Reflexive control occurs when the controlling organ conveys (to the objective system) motives and reasons that cause it to reach the desired decision, the nature of which is maintained in strict secrecy. A 'reflex' itself involves the specific process of imitating the enemy's reasoning or imitating the enemy's possible behavior and causes him to make a decision unfavorable to himself. ${ }^{50}$

The task, so to speak, is to find a weak link in the enemy's "filter" and exploit it. The filter is "made up of concepts, knowledge, ideas and experience," and it can be targeted by an information weapon defined as a "specially selected piece of information capable of causing changes in the information processes of information systems in accordance with the intent of the entity using the weapon." ${ }^{21}$ This is what in Soviet terminology was meant by disinformation. As described by Ladislav Bittman in an essay published in 1985, disinformation is "a carefully constructed, false message that is secretly introduced into 
the opponent's communication system to deceive either his decision-making elite or public opinion." 52 For this purpose, various channels were used, including rumours, 265 forgeries, manipulative political actions, agents of influence, front organizations, and other means. ${ }^{53}$ As explained by Bittman, Soviet disinformation operations were:

Acts of opportunity reflecting the long-term interests of the Soviet Union. Their primary objective is to add another drop of venom to the opponents' internal system which the expectation that eventually, after a certain period of time, quantity will become quality and the patient will die. ${ }^{54}$

It should be emphasized that each of these concepts discussed in this chapter describes techniques that can be used both in the domestic context and as a foreign and security policy resource. The concept of Active Measures is predominantly used in Western literature on Soviet influence operations during the 1980s, and thus it reflects the Western understanding of the Soviet foreign policy toolbox. In fact, it can be argued that the current discussion on Russia's hybrid war reflects this earlier debate, at least when it comes to conceptualizing Russia's actions with terminology that is understandable to the Western expert community. However, the bottom line of this discussion then and now is that none of the techniques used for influencing others (abroad and at home) work in isolation.

As defined in a study published in 1984, Active Measures are "certain overt and covert techniques for influencing events and behaviour in, and the actions of, foreign countries." 55 Active Measures may entail the following objectives:

- influencing the policies of another government

- undermining confidence in its leaders and institutions

- disrupting the relations between other nations

- discrediting and weakening governmental and non-governmental opponents.

The means of conducting these actions include:

- attempts to deceive the target

- attempts to distort the target's perceptions of reality.

The research published in 1984 on Soviet Active Measures distinguishes between "overt propaganda" and "covert political techniques." 56 Overt propaganda is defined as "written or oral information which deliberately seeks to influence and/or manipulate the opinions and attitudes of a given target grouping." Characteristic features of Soviet overt propaganda, according to the study, were its continuity, flexibility, and adaptability. Soviet propaganda was designed to work on the target for an extended period of time, and only the intensity of the campaign varied. Propaganda was flexible in the sense that the Soviets were able to adapt to changing circumstances rapidly and coordinate words with actions promptly. Furthermore, "intentional misrepresentation" of events and phenomena was utilized as one of the tools of deception. ${ }^{57}$ There was nothing peculiar about these techniques in the Soviet view. Since propaganda in general was considered an integral part of the socialist system, the use of Active Measures was regarded as a legal and legitimate 300 part of the country's foreign policy. ${ }^{58}$ 
A general conclusion drawn from previous research is that the success of a disinformation operation "depends on the willingness of the audience to be deceived." To achieve this outcome, "the perpetrator of the disinformation uses the language the audience wants to hear." ${ }^{59}$ Describing Western susceptibility to Soviet disinformation, Uri Ra'nan remarks that Western media adopted "language usage in the Soviet manner," for example, by making reference to "Afghan terrorists" and "routinely describing almost any anti-Western guerrilla campaign as a resistance movement." ${ }^{60}$ Today, a similar phenomenon can be observed in the context of war in Ukraine. Western politicians and publicist refer to the war in Ukraine using the Russian vocabulary of "civil war." Another example is a generic reference to the "NATO enlargement." The frame of interpretation is geopolitical advance of the military alliance towards Russia, rather than the choice made by individual countries upon their sovereign right.

Finally, as noted by Maurice Tugwell at a conference organized back in 1985, "deception, both concealment and misrepresentation, aims at intellectual domination-at putting the West in a state of ignorance about Soviet activities and intentions that is linked to a sense of looming power. The desired psychological outcome is to displace faith in selfdefence with faith in appeasement." ${ }^{61}$ The Soviets did not achieve this objective with regard to the Nordic region. The next section will discuss obstacles that Russian strategic deception encounters in this region today.

\section{The use of asymmetric methods in the Nordic context: a mission impossible?}

In March 2017, Foreign Policy published an article that highlighted resilience of the Finnish public to Russian influence attempts. The authorities interviewed for the story argued that Finland's strong public education system, long history of balancing Russia, and a comprehensive government strategy, "allow it to deflect coordinated propaganda and disinformation." ${ }^{\prime 2}$ Although Finland clearly is not the main target of Russia's propaganda operations in Europe, the Finnish authorities have identified around 20 clear information operations against Finland in the past few years. ${ }^{63}$ Similar observations have been made in Sweden where Russian influence operations have been reported. ${ }^{64}$ In 2016, the foreign ministers of Sweden and Finland issued a joint declaration in which they condemn the Russian propaganda and disinformation across the region. ${ }^{65}$

Russian attempts to influence the US presidential elections in 2016 and subsequent debate in the US about ways to counter such influence, has concretized this debate in the Nordic countries as well. In Sweden, the Civil Contingencies Agency (MSB) is responsible for monitoring the threat of foreign information campaigns. ${ }^{66}$ In Finland, this task is distributed among government authorities. Since 2017, Finland hosts the EU level agency with a task of countering hybrid threats. The Hybrid COE is a coordinating unit that will contribute to the joint understanding, and possible joint counter-actions at the EU level. These examples tell about a heightened sense of threat of information operations towards the EU and individual EU member-states. Thus, the question no longer is whether Russia is trying to influence the Nordic countries through different measures, but how effective or intensive this influence is. Previous research on this topic provides a mixed message.

Most of the recent research has focused on Russian attempts at influencing public opinion in foreign countries through the traditional media and social media platforms. From the mid-2000s onwards, Russia has created external broadcasting services aimed 
exclusively at the Western audience, operating in Western languages and according to Western standards. The two most emblematic actors are RT and Sputnik, in addition to a wide network of information websites and groups on social media networks. Contrary to the Soviet times, Moscow can now easily and steadily reach Western consumers, and thus deliver its propaganda and disinformation messages directly. And, what is most important, in a form that fits into the Western media environment, thus making the detection of false narratives a challenge. ${ }^{67}$

However, previous research ${ }^{68}$ has shown that Russia's attempts to foster its point of view concerning the conflict in Ukraine have been less successful. The research conducted by the Riga Stratcom Center in August 2017, shows that in Finland only a minority of the respondents knew Russia's two main foreign propaganda channels: Sputnik and RT. A majority of the respondents do not know or never watch these channels. ${ }^{69}$ However, respondents had a clear idea that the news provided by the Russian state media were not trustworthy. Since a clear minority was familiar with these channels, this conclusion seems to have been made on the basis of information about these media. Furthermore, the main media outlets in Finland and Sweden remain critical towards Russian meta-narratives about the events leading towards the conflict. Both countries have also confirmed their support for EU sanctions. In this regard, the Russian propaganda and disinformation has had little impact in changing the government position.

A majority of the recent research on Russian information influence seems to focus on the news media and social media platforms (Facebook, Twitter). The significance of public opinion in the democratic decision-making process explains why authorities are concerned about these channels of influence. Another, perhaps more practical, reason for this situation is that there is data available on the fluctuation of narratives, bots, and networks. Whereas, it is much harder to trace through the public resources whether other means of asymmetric approach are used in a particular context. The research on the initial period of war in Ukraine, on networks operating around the elections in Germany and France, and the attempts to influence politicians in Sweden and Lithuania, provide glimpses of what the Active Measures are about in today's context.

\section{Conclusion}

Russian researchers have questioned an interpretation that the post-Crimean security situation resembles that of the Cold War. As argued in the IMEMO 2015 forecast, the basic principles of the Cold War era's system of international relations, such as nuclear deterrence, are no longer applicable in the same way as during the Cold War. A new element has emerged to this equation, namely, the deep inter-dependence of the global economic system that provides a "safety belt" against irreversible steps. Furthermore, Russian analysts argue that strong, and what is most important, diverging economic interests among the EU member-states will ensure that the EU does not have a unified policy against Russia. Finally, the analysts argue that multiple regional and global threats (e.g., WMD proliferation) require Russia's participation, or at least its consent or neutrality, and therefore, an old-type cold war would be unthinkable. ${ }^{70}$

At the same time, the above analysis of an asymmetric approach shows that conceptualizations developed during the Cold War such as strategic deception, have retained their significance in Russia's foreign and security policy. Thus, even if the current situation 
does not formally fit what is historically known as the Cold War, certain practices used in 390 neutralizing (as Russians view the task) the conflict potential, even threat towards Russia's national interests, do fit the pattern. ${ }^{71}$ The key assumption in this regard is that the use of the "organizational weapon"-be it a front organization in the 1960s (e.g., the World Peace Council) or a pseudo-political entity operating in the Eastern Ukraine (the so called Donetsk National Republic, DNR), is controlled from Moscow, and thus, is systemic, not haphazard.

Two issues should be highlighted in this connection. First, while Active Measures have a systemic character (and certain patterns can be observed in themes and narratives), Lenin's dictum about working with material is still important. This means that the context (historical relations with Russia, criminal environment, media space, etc.) shapes the ways in which Active Measures are used. The second factor to consider is perhaps obvious, but still worth mentioning. It is taken for granted in the Russian debate that the political (and economic) rallies, populist movements, and popular uprisings, emerge as a consequence of external (state) influence. Often this type of argumentation is used in securitizing the political opposition in Russia, most recently, in the context of presidential elections. ${ }^{72}$ But it can also lead to false expectations (mirror-imagining) during the conflict, and thus, hamper the resolution of the conflict.

What should be emphasized in the end is that technological development in the information sphere and global economic interdependency have fundamentally changed the societal and political context in which Active Measures are carried out. ${ }^{73}$ The outcome is a hybrid-where the Cold War era sentiments about a threat towards the state sovereignty and political regime are used in legitimating a preventive, asymmetric approach that in turn, takes advantage of the new technologies and gaps emerging between and within societies in flux.

\section{Disclosure statement}

No potential conflict of interest was reported by the author.

\section{Notes}

1. The full text is available at http://www.ieee.es/Galerias/fichero/OtrasPublicaciones/ Internacional/2016/Russian-National-Security-Strategy-31Dec2015.pdf.

2. Russian National Security Strategy, Article 12 (Presidential edict N683, approved December 31, 2015), http://www.ieee.es/Galerias/fichero/OtrasPublicaciones/Internacional/ 2016/Russian-National-Security-Strategy-31Dec2015.pdf.

3. Ibid., Article 12.

4. Ibid. S. Roberts, A. Marin, A. Moshes, and K. Pynnöniemi, "The Eurasian Economic Union. Breaking the pattern of Soviet Integration? The Finnish Institute of International Affairs," FIIA Analysis 3, September 2014. https://www.fiia.fi/julkaisu/the-eurasian-economic-union.

5. Russian National Security Strategy, Article 13 (Presidential edict N537, approved May 12, 2009).

6. Russian Military Doctrine 2014, (Presidential edict N2976N, approved December 25, 2014).

7. Russian National Security Strategy 2015, Articles 87, 104.

8. Russian National Security Strategy 2015, Article 87.

9. Sergey Karaganov, "Time to End the Cold War in Europe," Russia in Global Affairs, April 28, 2014, http://eng.globalaffairs.ru/pubcol/Time-to-End-the-Cold-War-in-Europe-16599; see also 
Sergey Karaganov, "Europe and Russia: Preventing a New Cold War," Russia in Global Affairs, June 7, 2014, http://eng.globalaffairs.ru/number/Europe-and-Russia-Preventing-a-New-ColdWar-16701.

10. Sergey Karaganov, "How to Avoid a Second Afghanistan," Russia in Global Affairs, July 28 2014, http://eng.globalaffairs.ru/pubcol/How-to-avoid-second-Afganistan-16858.

11. Russian Military Doctrine 2014 (Presidential edict N2976N, approved December 25, 2014); Russian National Security Strategy 2015.

12. A. Dynkin et al., "Rossiya i Mir: 2014. Ekonomika i Vneshnyaya Politika, Ezhegodnyi Prognoz, IMEMO 2013, 89”. https://www.imemo.ru/index.php?page_id=645\&id=1696.

13. A. Dynkin et al., "Russia and the World: 2015. IMEMO Forecast," New Perspectives 2, no. 22, (2014): 115. http://ceenewperspectives.iir.cz/2015/08/22/russia-and-the-world-2015-imemoforecast/.

14. A. Dynkin et al., "Russia and the World: 2017. IMEMO Forecast," New Perspectives 25, no. 1 (2017): 86. http://perspectives.iir.cz/download/russia-and-the-world-2017-imemo-forecast-2/. See also A. Dynkin et al., "Rossiya i Mir: 2013. Ekonomika i Vneshnyaya Politika, Ezhegodnyi Prognoz, IMEMO 2012". https://www.imemo.ru/index.php?page_id=645\&id=47.

15. A. Dynkin et al., "Rossiya i Mir: 2018. Ekonomika i Vneshnyaya Politika, Ezhegodnyi Prognoz, IMEMO 2017", 103. https://www.imemo.ru/files/File/ru/publ/2017/2017_025.pdf.

16. Russian National Security Strategy 2015, Article 36.

17. On the indirect approach, see B. H. Liddell Hart, Strategy: Indirect Approach (London: Faber and Faber, 1967).

18. Mahmut Gareev, If War Comes Tomorrow? The Contours of Future Armed Conflict (London: 455 Frank Cass, 1998).

19. Mahmut Gareev, "Strategicheskoe Sderzhivanie: problemy i resheniya," Krasnaya Zvezda, October 8, 2008.

20. See Jonsson and Seely for a description of Russian activities in the Ukraine conflict using the concept of full-spectrum conflict. Oscar Jonsson and Robert Seely, "Russian Full-Spectrum Conflict: An Appraisal After Ukraine," Journal of Slavic Military Studies 28, no. 1 (2015): 1-22.

21. National Security Strategy 2015, Art. 36.

22. Russian Military Doctrine 2014, Art. 15 (Presidential edict N2976N, approved December 25, 2014).

23. A. V. Manoilo, ed., Operatsii informatsionno-psihologicheskoi voiny. Kratkii entsiklopedicheskii slovar-spravochnik (Moskva: Goryachnaya Linya - Telekom, 2011), 72; Heidi Berger, Venäjän informaatio-psykologinen sodankäyntitapa terrorismintorjunnassa ja viiden päivän sodassa (Helsinki: Maanpuolustuskorkeakoulu, 2010); Keir Gilles, "Russia's New Tools for Confronting the West, Continuity and Innovation in Moscow's Exercise of Power" (Research Paper, Chatham House, London, 2015), 28-29, https://www.chathamhouse.org/ sites/files/chathamhouse/publications/research/2016-03-21-russias-new-tools-giles.pdf (accessed March 28, 2016).

24. Irina Nagornyh, Ivan Safronov, and Elena Tsernenko, "С “цветных революций” хотят снять камуфляж," Kommersant, March 4, 2015; Irina Nagornyh and Ivan Safronov, "Минобороны подключается к борьбе с “цветными революциями," Kommersant, June 24, 2015. See also Franke, "War by Non-military Means"

25. Andrew Wilson, Virtual Politics: Faking Democracy in the Post-Soviet World (New York, NY: Yale University Press, 2015); Gleb Pavlovskii, 2016/Terminus! Neopropaganda, Eksalatsiya, i Predel Naslazhennii Sistemy RF (Moskva: Evropa, 2016).

26. The concept of soft power is explained as part of geopolitical struggle, and, at least in public discussion, it is used as a synonym to information war, thus rendering it incomprehensible to debate based on the original conceptualization. A. V. Radchuk, "Myagkaya Sila i Geopolitika: Uroki Ukrainskogo," in Voenno-Politicheskie Aspekti Bezopasnosti Rossii v Svete Krizisa na Ukraine, ed. G.G. Tishenko (Moskva: RISI, 2015).

27. Russian National Security Strategy 2009; National Security Strategy 2015.

28. Paraphrased in Peter Kenez, The Birth of the Propaganda State: Soviet Methods of Mass Mobilization 1917-1929 (Cambridge: Cambridge University Press, 1985), 123. Emphasis added. 
29. These include propaganda campaigns organized on the occasion of the October Revolution and other important anniversaries as well as campaigns for "World Peace" or the struggle against famine. Kenez (see note 28), 122.

30. B. Semmel, Marxism and the Science of War (Oxford: Oxford University Press, 1981), 227. An excerpt from Lenin's article On Guerrilla Warfare first published in Prolety on September 30, 1906. Translated as Guerrilla Action in Semmel and warfare at: https://www.marxists.org/ archive/lenin/works/1906/gw/.

31. Ibid., 229. Already earlier, in his essay titled What Is to Be Done? Lenin fought against "spontaneity" and explained what the "organization of the revolutionaries" should look like. This was important because there could be no middle ground, and any sign of unprofessionalism would mean the strengthening of bourgeois ideas. Lenin 1902.

32. Ibid., 228. Stalin is often mentioned in this context for he was in charge of the propaganda work in Baku financed by the proceeds from bank raids. J. C. Clews, Communist Propaganda Techniques (London: Methuen, 1964), 14.

33. Semmel (see note 30), 211-12. An excerpt from "The Lessons of the Moscow Uprising," first published in Prolety on August 29, 1906. In this article, Lenin called for the organization and control of mass terror as part of revolutionary tactics. Emphasis added.

34. Kenez (see note 28), 123-26; Clews (see note 32), 12-14.

35. Dictionary of Scientific Communism (Soviet Union: Progress Publishers, 1984), 183.

36. Richard Shultz and Roy Godson, Dezinformatsia: Active Measures in Soviet Strategy (New York, NY: Bergamon Brassey's, 1984), 19. Lenin's essay What Is to Be Done? is cited in this connection.

37. Cited in Shultz and Godson (see note 36), 19.

38. Manoilo (see note 23); see also the War and Peace dictionary <http://voina-i-mir.ru/>; Russian military dictionaries <http://encyclopedia.mil.ru/encyclopedia/dictionary.htm>.

39. Valerii Korovin, "Effekt aifona," Literaturnaya Gazeta, November 12, 2014.

40. Sergei Glazyev, "От общества потребления к обществу развития," Rossiiskaya Federatsiya Segodnya, January 10, 2013; Elena Larina, 'Инженеры хаоса: почему теракт в Париже совершили агенты спецслужб' (Engineers of Chaos: Why a terrorist attack at Paris was conducted by Special Forces) (IA Regnum, January 15, 2015).

41. Bogdanov was the Bolshevik movement's "second-in-command" (1904-1908) and became a non-person in Soviet science during the Stalin era. Ilmari Susiluoto, The Origins and Development of Systems Thinking in the Soviet Union (Helsinki: Suomalainen tiedeakatemia, 1982).

42. Susiluoto (see note 41), 50-51.

43. Nagornyh, Safronov, and Tsernenko (see note 24).

44. A. Gapich and D. A. Lushnikov, Technology of Color Revolutions, RIOR INFRA-M, Moscow, 2014, Second Edition. First Published 2010, 7-9.

45. A. S. Brychnkov and G. A. Nikonorov, "Colored Revolutions in Russia: Possibility and Reality," Vestnik Akademii Voennih Nauk 3 (2017): 4.

46. Ibid.

47. E. A. Derbin, "Methodological Aspects of Analyzing Modern Warfare," Vestnik Akademii Voennyh Nauk 1 (2017): 16.

48. V. S. Ovchinskii and I. Sundiev, "Organizatsionnoe Oruzhie," Isborskii Klub, 2013, http:// www.dynacon.ru/content/articles/1466/.

49. Cited in Timothy L. Thomas, "Russia's Reflexive Control Theory and the Military," Journal of Slavic Military Studies 17, (2004): 2.

50. Ibid., 5. The encyclopedia of information-psychological war from 2011 includes the term upravlenie refleksivnoe (reflexive control). Manoilo (see note 23), 446.

51. Thomas (see note 49), 11.

52. Ladislav Bittman, “The Language of Soviet Disinformation," Contemporary Soviet Propaganda and Disinformation: A Conference Report (United States Department of State, 1987), 113.

53. Shultz and Godson (see note 36), 195.

54. Bittman (see note 52), 119. 
55. Shultz and Godson (see note 36), 193; see also United States Department of State 1989.

56. Also referred to as disinformation, covert propaganda aims to "lead the target to believe in the veracity of the message and consequently to act in the interests of the nation conducting the disinformation operation." Ibid., 195.

57. Ibid., 34-36.

58. The five broad objectives of the Soviet foreign policy included the following: 1) to preserve, enhance and expand security in areas under the influence of the USSR; 2) to divide the Western opponents of the Soviet Union by driving wedges between them and disrupting alliance systems; 3 ) to retain the primary role of the USSR in the Communist world; 4) to promote "proletarian internationalism" and those "national liberation movements" that are under Communist control or serve Soviet interests and 5) to minimize risks and avoid serious involvements on more than one front at any given time. Shultz and Godson (see note 36), 10.

59. Bittman (see note 52), 115. Emphasis added.

60. Shultz and Godson (see note 36).

61. United States Department of State. Contemporary Soviet Propaganda and Disinformation. (A conference Report. Airlie, Virginia, June 25-27, 1985. Department of State Publication 9536. Bureau of Intelligence and Research, Office of Active Measures Analysis and Response). Released March (1987), 51.

62. Reid Standish, "Why Is Finland Able to Fend off Putin's Information War?," Foreign Policy, 560 March 1, 2017 http://foreignpolicy.com/2017/03/01/why-is-finland-able-to-fend-off-putinsinformation-war/.

63. Jussi Rosendahl and Tuomas Forsell, "Finland Sees Propaganda Attack from Former Master Russia," Reuters, October 19, 2016, https://www.reuters.com/article/us-finland-russiainformationattacks/finland-sees-propaganda-attack-from-former-master-russia-idUSKCN 565 12J197? feedType $=$ RSS\&feedName $=$ topNews.

64. Martin Kragh and Sebastian Åsberg, "Russia's Strategy for Influence through Public Diplomacy and Active Measures: The Swedish Case," Journal of Strategic Studies. doi:10.1080/01402390.2016.1273830.

65. Timo Soini and Margot Wallstrom, "Together We Are Stronger," Helsingin Sanomat, 570 September 12, 2016, https://www.hs.fi/paakirjoitukset/art-2000002920395.html.

66. Emma Löfgren, "How Sweden's Getting Ready for the Election-year Information War," The Local, November 7, 2017, https://www.thelocal.se/20171107/how-swedens-getting-ready-forthe-election-year-information-war.

67. The general view in the 1980s seems to have been that some Soviet campaigns were successful in influencing large numbers of people, while many Active Measures, in particular forgeries, led to failure. United States Department of State, Contemporary Soviet Propaganda and Disinformation, 47.

68. Pynnöniemi and Racz, Fog of Falsehood.

69. NATO StratCom Center of Excellence, Russia's footprint in the Nordic - Baltic information environment, Report 2016/2017, January 2018, https://www.stratcomcoe.org/russias-footprintnordic-baltic-information-environment-0.

70. A. Dynkin, Russia and the World: 2015 (see note13), 114-115.

71. National security strategy 2015.

72. The Federation Council has initiated in summer 2017 a process to prepare changes to the legislation ensuring protection of Russia from interference to presidential elections in 2018. Federation Council, "On conclusions of parliamentary hearing about preventing interference to the internal affairs of the Russian Federation: legislation and legal practices" (Decree N 162SF, June 14, 2017).

73. H. Margetts, ed., Political Turbulence: How Social Media Shape Collective Action (Princeton 590 and Oxford: Princeton University Press, 2016). 